\title{
An in Vitro System from Plasmodium falciparum Active in Endogenous mRNA Translation
}

\author{
Ana Ferreras, Ledia Triana, Heriberto Correia, Erlinda Sánchez, Flor Herrera ${ }^{+}$
}

\author{
Centro de Investigaciones Biomédicas, Facultad de Ciencias de la Salud, Universidad de Carabobo-Núcleo \\ Aragua, Apartado 2351, Maracay, Edo. Aragua, Venezuela
}

An in vitro translation system has been prepared from Plasmodium falciparum by saponin lysis of infected-erythrocytes to free parasites which were homogeneized with glass beads, centrifuged to obtain a S-30 fraction followed by Sephadex G-25 gel filtration. This treatment produced a system with very low contamination of host proteins $(<1 \%)$. The system, optimized for $\mathrm{Mg}^{2+}$ and $\mathrm{K}^{+}$, translates endogenous $\mathrm{mRNA}$ and is active for $80 \mathrm{~min}$ which suggests that their protein factors and $\mathrm{mRNA}$ are quite stable.

Key words: Plasmodium falciparum - protein synthesis - cell free translation - parasite lysate

Very scarce information about the mechanism of protein synthesis in Plasmodia is available. It is mainly due to the difficulties of preparing an efficient cell-free translation system which would make possible the translation of parasite mRNAs. Achieving this goal is a basic requirement for the study of the biochemistry of translation and the regulatory mechanisms of these parasites. Moreover, this knowledge is of potential importance for the control of malaria since reports in the literature show that there are significant distinctions between the protein synthesis mechanism of the host and that of the parasite (Wallach \& Kilejian 1982, Deans et al. 1983, Perkins 1988, Surolia \& Padmanaban 1991, Cambie et al. 1991, Elmendorf et al. 1992, Li et al. 1994a, b).

Results obtained using an in vitro translation system from Plasmodium lophurae suggest that components of the protein synthesis mechanism may be essential for the specific translation of parasite mRNAs (Wallach 1982). It has also been reported that chloroquine inhibits heme-dependent protein synthesis in P. falciparum (Surolia \& Padmanaban 1991) concomitantly with the phosphorylation of the parasite initiation factor $2 \alpha$ (eIF$2 \alpha$ ). These data may also explain the vulnerability of the trophozoite stage (the most active in protein

\footnotetext{
This research was supported in part by Fundacite-Aragua, by the Consejo de Desarrollo Científico y Humanístico of the Universidad de Carabobo and by the Consejo Nacional de Investigaciones Científicas y Tecnológicas. ${ }^{+}$Corresponding author. Fax: 58-43-713456. E-mail: fherr@telcel.net.ve

Received 7 May 1999

Accepted 13 December 1999
}

synthesis) to chloroquine (Cambie et al. 1991). Recently, it has been suggested that the antibiotics thiostrepton (McConkey et al. 1997) and micrococcin (Rogers et al. 1998) target protein synthesis in the plastid-like organelle of the parasite. Furthermore, some reports suggest the existence of metabolic interdependence between extracellular energy metabolism and protein synthesis activity within the parasite (Elmendorf et al. 1992).

One interesting feature of Plasmodium species is that structurally distinct ribosomal RNA genes are expressed at different stages of the parasite's life cycle ( $\mathrm{Li}$ et al. 1994a, b, Rogers et al. 1996). It is possible that the structural alterations of ribosomes mediate the selection of specific families of mRNA for translation. Changes in proteins synthesized by P. falciparum, have been reported as it undergoes the morphological transitions from asexual as well as sexual blood stages (Deans et al. 1983, Perkins 1988, Baker et al. 1995, Schmidt et al. 1998) which possibly reflects different translational demands in varying intracellular environments or during distinct cellular activities.

The development of a cell-free translation system from $P$. falciparum also opens the possibility for identifying target antigens which may be relevant for the acquisition of protective immunity (Druilhe et al. 1997, Greenwood 1997). This issue is a major current goal in the global malaria control strategy.

In this study we describe a cell-free system from $P$. falciparum that retains active polysomes capable of carrying out the elongation and termination steps of parasite polypeptide synthesis.

\section{MATERIALS AND METHODS}

Maintenance of the malarial parasite - $P$. falciparum FCB1 strain, a local isolate from Co- 
lombia, was cultured in vitro according to the candle jar method (Trager \& Jensen 1976).

Isolation of malaria parasites from infected blood - Parasites were synchronized using 5\% Dsorbitol (Freeman \& Holder 1983) and the cultures were pooled at late trophozoite stage with $8-10 \%$ parasitaemia. The infected blood was centrifuged at $2,000 \mathrm{x} \mathrm{g}$ for $10 \mathrm{~min}$ at $4^{\circ} \mathrm{C}$. The pellet which contained the red cells was resuspended in $2 \mathrm{vol}$ of buffer A [20 mM Hepes/KOH pH 7.4; $2 \mathrm{mM}$ $\left.\mathrm{Mg}(\mathrm{OAc})_{2} ; 120 \mathrm{mM} \mathrm{KOAc}\right]$. Parasites were released from erythrocytes following a modified procedure described in Ruenwongsa (1985). The red cells were suspended in $2 \mathrm{vol}$ of $0.15 \%$ saponin in buffer $\mathrm{A}$. After incubation at $37^{\circ} \mathrm{C}$ for $30 \mathrm{~min}, 3 \mathrm{vol}$ of cold buffer $\mathrm{A}$ was added and the mixture was centrifuged $10,000 \mathrm{x} \mathrm{g}$ for $10 \mathrm{~min}$ at $4^{\circ} \mathrm{C}$. The pellet, containing the freed parasites was washed three times with the same buffer, and frozen at $-70^{\circ} \mathrm{C}$.

Preparation of the parasite cell-free system Free-parasites were resuspended in 2 vol of icecold lysis buffer $[50 \mathrm{mM}$ Tris/ $\mathrm{HCl} \mathrm{pH} \mathrm{7.4;} 100 \mathrm{mM}$ KOAc; $7 \mathrm{mM} \mathrm{Mg}(\mathrm{OAc})_{2} ; 380 \mathrm{mM}$ sucrose; 6.5 $\mathrm{mM}$ ß-mercaptoethanol; $0.14 \% \mathrm{vol} / \mathrm{vol}$ Triton X$100 ; 15 \mu \mathrm{M}$ leupeptin and 20 units of placental ribonuclease inhibitor]. Acid-washed glass beads $(0.1 \mathrm{~mm})$ equivalent to $2 \mathrm{~g} / \mathrm{vol}$ of parasites, were added and the suspension was stirred in a vortex for $1 \mathrm{~min}$ followed by $10 \mathrm{~min}$ incubation for cooling. After two-extra vortex-cooling cycles, the parasite homogenate was centrifuged at $12,000 \mathrm{x}$ $\mathrm{g}$ for $30 \mathrm{~min}$ at $4^{\circ} \mathrm{C}$. The supernatant was filtered through a Sephadex G-25 medium column equilibrated with buffer B [20 mM Hepes/KOH pH 7.4; $100 \mathrm{mM} \mathrm{KOAc} ; 3 \mathrm{mM} \mathrm{Mg}(\mathrm{OAc})_{2} ; 2 \mathrm{mM}$ DTT and $20 \%$ glycerol]. Fractions with the highest absorbance at $260 \mathrm{~nm}$ were pooled and used as the S-30 fraction (7-9 $\mu \mathrm{g} / \mu \mathrm{l}$ and $10-12 \mathrm{~A}_{260}$ units $\left./ \mathrm{ml}\right)$. A similar extract was prepared as described above from uninfected erythrocytes. Due to the low protein concentration of this cell extract (0.015-0.025 $\mu \mathrm{g} / \mu \mathrm{l})$, it was necessary to concentrate it approximately 20 times by lyophilization.

Isolation of ribosomes - The ribosomes were isolated according to Herrera et al. (1984). Some aliquots were treated with high salt and were labeled as high salt ribosomes (HSR).

Ribosome analysis - Ribosomes and HSR were analyzed on linear sucrose density gradient following the methodology described by Gasior et al. (1979).

Protein synthesis - Cell-free protein synthesis was carried out in a standard reaction mixture contained the following components in a volume of $50 \mu \mathrm{l}$ : $20 \mathrm{mM}$ Hepes/KOH pH 7.4; $100 \mathrm{mM} \mathrm{KOAc;}$ $5 \mathrm{mM} \mathrm{Mg}(\mathrm{OAc})_{2} ; 2$ mM DTT; $10 \%$ glycerol; 0.5 mM ATP; $0.1 \mathrm{mM}$ GTP; $20 \mathrm{mM}$ creatine phos- phate; $10 \mu \mathrm{g}$ of creatine phosphokinase; $40 \mu \mathrm{M}$ (each) of 19 aminoacids (except methionine) and $1.7 \mu \mathrm{M} \mathrm{L}-\left[{ }^{3} \mathrm{H}\right]$ methionine $(77 \mathrm{cpm} / \mathrm{pmol})$ and variable amounts of S-30 fraction as indicated in the legends to the Figures. Reactions were initiated with the addition of the S-30 fractions and incubated at $37^{\circ} \mathrm{C}$ for $60 \mathrm{~min}$. At the end of the incubation period the fractions insoluble in hot $\left(90^{\circ} \mathrm{C}\right) 10 \%$ trichloroacetic acid were prepared; the precipitates were collected on glass-fiber filters, washed, dried and counted in a scintillation counter.

Polyacrylamide gel electrophoresis - The proteins were analyzed by $12.5 \%$ SDS/PAGE according to Laemmli (1970). Some incubations for protein synthesis were performed using $\left[{ }^{35} \mathrm{~S}\right]$ methionine $(117,5 \mathrm{Ci} / \mathrm{mmol})$. Radioactively labeled proteins were electrophoresed and visualized by autoradiography.

Protein concentration determination - Protein concentration was determined as described by Lowry et al. (1951).

\section{RESULTS}

To develop the cell-free translation system from $P$. falciparum, we first free the parasites from erythrocytes to eliminate most of the contaminants. We determined that with a ratio of $2 \mathrm{vol}$ of $0.15 \%$ saponin to $1 \mathrm{vol}$ of erythrocytes, more than $90 \%$ of the cells were lysed (data not shown).

Comparison of the polypeptide pattern of parasite S-30 and that of extract of uninfected erythrocytes (Fig. 1) indicated the existence of parasite specific proteins which were absent from the control (Mrs of the prominent bands: 98, 62, 56, 52, and $40 \mathrm{kDas})$. Densitometric scanning of lane 1 (parasite proteins) and lane 2 (uninfected erythrocyte proteins), detected five major polypeptides (Mr 15, 28, 30, 46 and $69 \mathrm{kDas}$ ) from the uninfected erythrocytes that may be important contaminants in the parasite $\mathrm{S}-30$. The polypeptide with a $\mathrm{Mr}$ of about $15 \mathrm{kDa}$ may represent the globin chain. Taking it as a marker, we calculated the contamination of host proteins in the parasite S-30 fraction to be $<1 \%$.

Sedimentation of the ribosomes in sucrose gradients showed (Fig. 2A) that 55\% of the total 260 $\mathrm{nm}$ absorbing material is heavier than $80 \mathrm{~S}$ indicating the presence of polyribosomes. It was also found that the $P$. falciparum polyribosomal fraction was dissociated with high salt treatment (Fig. 2B). The large polyribosome and monosome peaks decrease from $55 \%$ and $45 \%$ to $22 \%$ in both cases, whereas the ribosomal subunit population $(60 \mathrm{~S}$ and 40 S) previously undetected increases to $56 \%$ with high-salt treatment.

The effect of the lysate concentration was tested on polypeptide synthesis directed by endogenous 


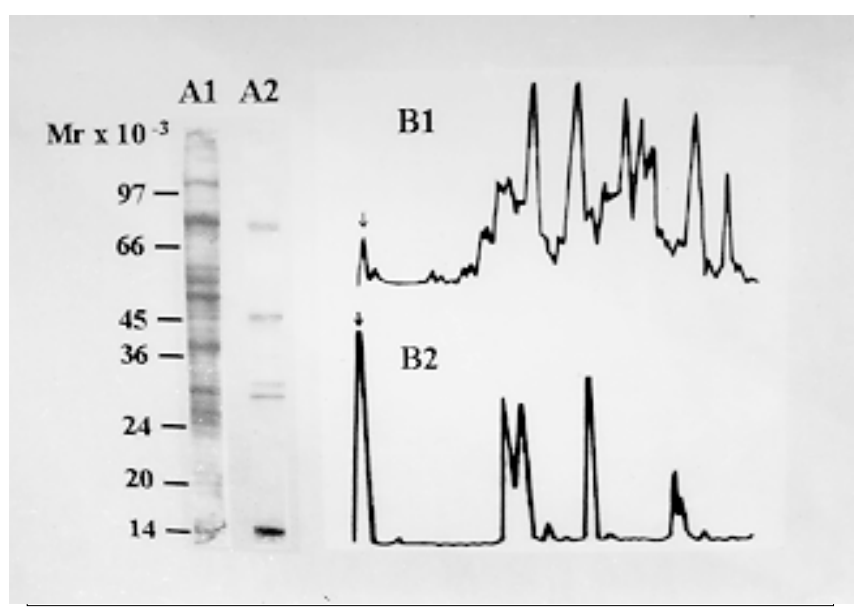

Fig. 1: PAGE of Plasmodium falciparum cell-free system and non-parasitized erythrocytes extract. Proteins present in the parasite S-30 fraction $(180 \mu \mathrm{g})$ (lane A1) and non-infected erythrocyte extract (45 $\mu \mathrm{g})$ (lane A2) were analyzed by SDS electrophoresis and stained with Coomassie Brilliant Blue. Molecular mass markers are indicated in kDa. Densitometric scans of lanes A1 and A2 shown in $\mathrm{B} 1$ and $\mathrm{B} 2$ respectively. The arrow shows the $15 \mathrm{kDa}$ polypeptide.

mRNA (Fig. 3). The best polymerization rate was found at concentrations around $2.8 \mathrm{mg}$ of protein/ $\mathrm{ml}$ which obtained up to a 24 -fold stimulation over the background activity. As the concentration of $\mathrm{K}^{+}$and $\mathrm{Mg}^{2+}$ ions play key roles in the fidelity as well as in the extent of translation (Roberts \& Paterson 1973) of several in vitro systems, we first optimized the $\mathrm{K}^{+}$and then $\mathrm{Mg}^{2+}$ concentrations. The

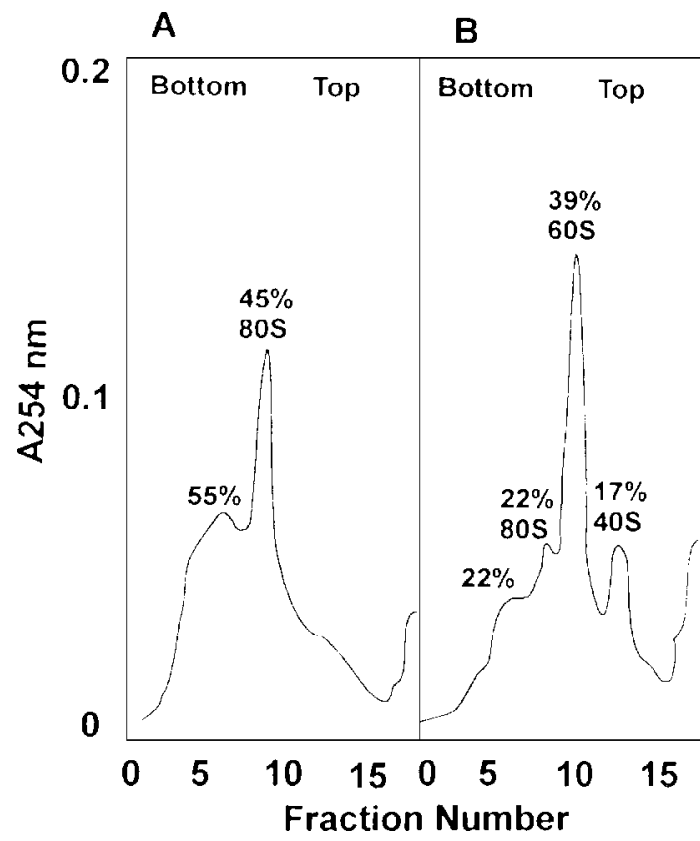

Fig. 2: analysis of polyribosomes and ribosomal subunits on a sucrose gradient. Plasmodium falciparum ribosomes were analyzed on a $15-40 \%$ linear sucrose gradient (A) without and (B) with high-salt treatment. Centrifugation and analytical procedures are described in Materials and Methods.

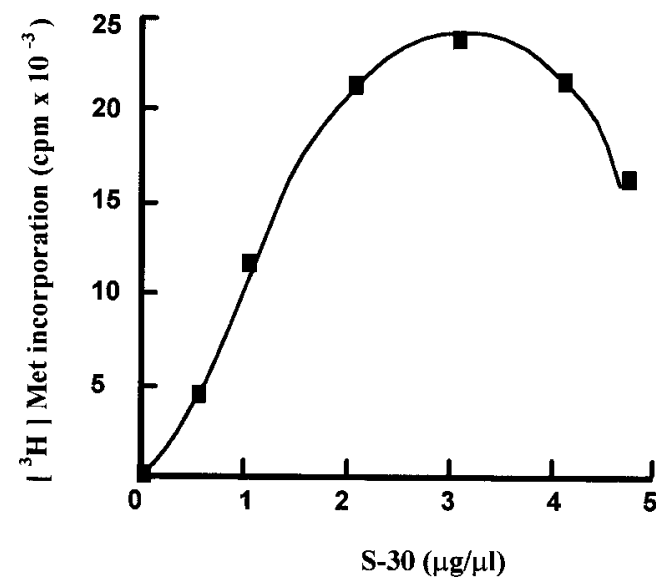

Fig. 3: optimization of Plasmodium falciparum cell-free system. Incubations were carried out for protein synthesis as described under Materials and Methods with varying amounts of $\mathrm{S}-30$ fraction for $60 \mathrm{~min}$. Protein synthesis was quantitated by $\left[{ }^{3} \mathrm{H}\right]$ methionine incorporation into hot TCA-insoluble material on each sample. Disks without sample were subjected to the same TCA treatment and were taken as blanks. Each datum point represents the mean incorporation observed in three different experiment

values found were $75 \mathrm{mM}$ for $\mathrm{K}^{+}$and $5 \mathrm{mM}$ for $\mathrm{Mg}^{2+}$ (data not shown). Next we determined that the protein synthesis continues up to $80 \mathrm{~min}$ and that the best temperature for this process was $37^{\circ} \mathrm{C}$ (data not shown).

To determine the proteins synthesized by the parasite cell-free system, $\left[{ }^{35} \mathrm{~S}\right]$ methionine was added to the incubation mix and products were analyzed by SDS/PAGE and autoradiography. Fig. 4 not only shows the clear presence of five main 
polypeptides of Mrs 60, 58, 55 , 45 and $29 \mathrm{kDas}$ but also reveals three minor bands of Mrs 105, 86 and $68 \mathrm{kDas}$.

Since it has been reported that hemin is needed for Plasmodia protein synthesis (Surolia \& Padmanaban 1991), the effect of hemin was examined in our parasite cell-free system. Addition of increasing amounts of hemin to the parasite lysate strikingly inhibits protein synthesis (Fig. 5).

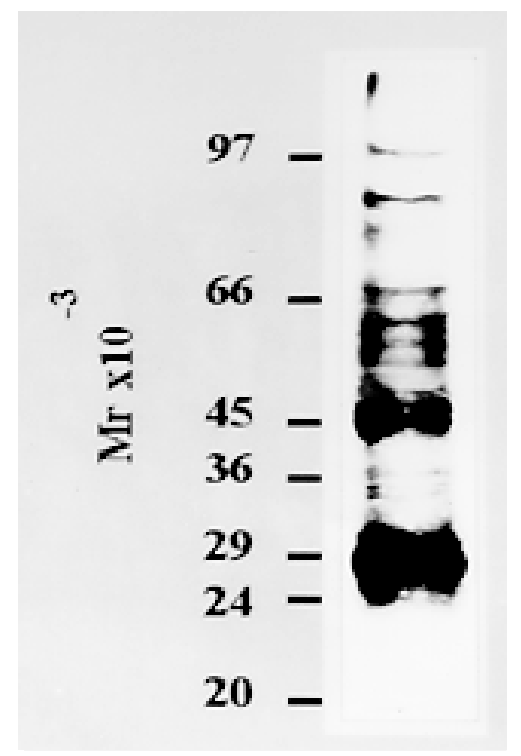

Fig. 4: proteins synthesized by the parasite cell-free system. The in vitro incorporation of $\left[{ }^{35} \mathrm{~S}\right]$ methionine into parasite proteins was carried out by incubating the labeled amino acid with the parasite lysate and products were analyzed on SDS/PAGE followed by autoradiography as described in Materials and Methods. Molecular mass markers are indicated on the left.

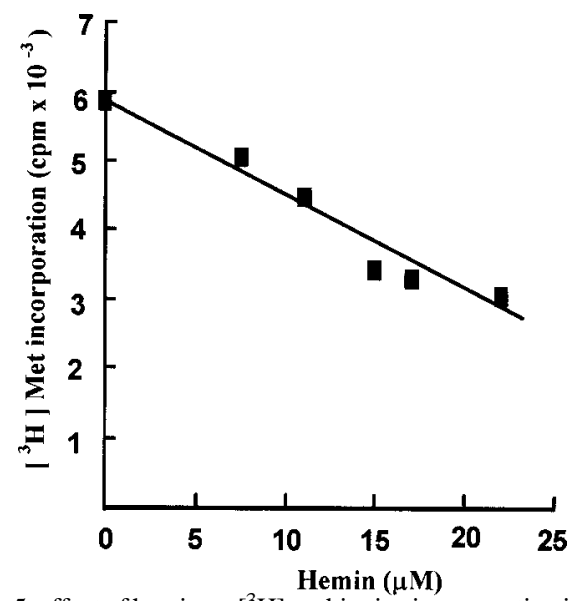

Fig. 5: effect of hemin on $\left[{ }^{3} \mathrm{H}\right]$ methionine incorporation into proteins of the parasite. Protein synthesis was assayed as described in the text. The parasite $S-30$ fraction $(140 \mu \mathrm{g})$ and other components were incubated with varying amounts of hemin at $37^{\circ} \mathrm{C}$ for 30 min. Quantitation of protein synthesis is as in Fig. 3.

\section{DISCUSSION}

The preparation of a cell-free system from the blood stages of malaria parasites involves the efficient lysis of the erythrocyte membrane with saponin which can apparently permeabilize (by intercalating with cholesterol) selectively the erythrocyte plasmatic and parasite vacuolar membranes without disrupting the parasite plasmatic membrane (Crary \& Haldar 1992). However, it is well known that the parasites freed by the saponin-lysis method are enclosed within the collapsed red cell membrane (Aikawa \& Cook 1972) and therefore, it is possible that proteins from this membrane or remnant hemoglobin could be present in the parasite S-30 fraction. In this study this possibility is unlikely to be a significant factor, since it was determined that more of $99 \%$ of the polypeptides of the parasite extract correspond to parasite proteins (Fig. 1).

Analysis of the polysomes of our cell-free system showed nearly equimolar quantities of monosomes and large polysomes (Fig. 2). This is in contrast to other Plasmodia cell-free systems in which the polyribosomes represented only $10 \%$ (Wallach \& Kilejian 1982). This data suggest that the $P$. falciparum system is actively engaged in protein synthesis, since most cells studied which are highly active in mRNA translation have mainly large polysomes (Woodland 1974).

We determined the optimal conditions for parasite protein synthesis (Fig. 3). Using these conditions the parasite $\mathrm{S}-30$ fraction is able to translate endogenous mRNA giving about 25-fold stimulation over the activity at time zero. This represents an activity significantly higher than that described for other Plasmodium systems (Surolia \& Padmanaban 1991). This translation can continue up to 80 min which suggests that protein factors and mRNA of the system are quite stable.

In addition, the incorporation of $\left[{ }^{35} \mathrm{~S}\right]$ methionine into polypeptides with high molecular masses suggests strongly that the parasite cell-free system contains sufficient amount of polyribosomes, tRNA, aminoacyltRNA synthetases and factors that allow the system to complete the steps of elongation and termination of the protein synthesis mechanism (Fig. 4).

We found that our in vitro translation system is not dependent upon exogenous hemin (Fig. 5). This finding is in apparent contradiction with the data reported by Surolia and Padmanaban (1991). They observed that addition of heme in vitro stimulated cell-free Plasmodium protein synthesis strikingly. Probably, in our conditions, the parasite lysate retains sufficient amounts of endogenous heme and therefore it is not rate-limiting for mRNA translation. 
We have described a cell-free system prepared from P. falciparum trophozoites able to translate endogenous mRNA. Work is now in progress to determine the nature of the proteins synthesized by the system.

This Plasmodium cell-free system can provide an useful tool to investigate the biology of the parasite and from which potential benefits like evaluation of the effects of a variety of drugs in Plasmodia translation could be derived.

\section{ACKNOWLEDGEMENT}

To Drs Ricardo Montoreano, Edmundo Cayama, Francisco Triana and Lic. Elizabeth Ferrer for helpful discussions, to Maria Briceño for culturing parasites and to Lic. Rafael Medina for helping us with the photographic technique.

\section{REFERENCES}

Aikawa M, Cook RT 1972. Plasmodium: electron microscopy of antigen preparations. Exp Parasitol 31: 67-74.

Baker D, Thompson J, Daramola OO, Carlton J, Targett G 1995. Sexual-stage-specific RNA expression of a new Plasmodium falciparum gene detected by in situ hybridization. Mol Biochem Parasitol 72: 193-201.

Cambie G, Caillard V, Beaute-Lafitte A, Ginsburg H, Chabaud A, Landau I 1991. Chronoterapy of malaria: identification of drug-sensitive stage of parasite and timing of drug delivery for improved therapy. Ann Parasitol Hum Comp 66: 14-21.

Crary JL, Haldar K 1992. Brefeldin A inhibits protein secretion and parasite maturation in the ring state of Plasmodium falciparum. Mol Biochem Parasitol 53: 185-192.

Deans JA, Thomas AW, Inge PMG, Cohen S 1983. Stage-specific protein synthesis by asexual blood stage parasites of Plasmodium falciparum. Mol Biochem Parasitol 8: 45-51.

Druilhe P, Sabchreon A, Bauharoun-Tayaoun H, Oeuvray C, Perignon JL 1997. In vivo veritas: lessons from immunoglobulin-transfer experiments in malaria patients. Ann Trop Med Parasitol 91: S37-S53.

Elmendorf HG, Bangs JD Haldar K 1992. Synthesis and secretion of proteins by released malarial parasites. Mol Biochem Parasitol 52: 215-230.

Freeman RR, Holder AA 1983. Surface antigens of malaria merozoites. A high molecular weight precursor is processed to an $83,000 \mathrm{~mol} \mathrm{wt}$ form expressed on the surface of Plasmodium falciparum merozoites. J Exp Med 158: 1647-1653

Gasior E, Herrera F, Sadnik I, McLaughlin C, Moldave K 1979. The preparation and characterization of a cell-free system from Saccharomyces cerevisiae that translates natural messenger ribonucleic acid. $J$ Biol Chem 254: 3965-3969.

Greenwood BM 1997. What's new in malaria control? Ann Trop Med Parasitol 91: 523-532.

Herrera F, Moreno N, Martínez JA 1984. Increased ribosomal affinity for mRNA causes resistance to edeine in a mutant of Sacharomyces cerevisiae. Eur J Biochem 145: 339-344.
Laemmli UK 1970. Cleavage of structural proteins during the assembly of the head of bacteriophage T4. Nature 227: 680-685.

Li J, McConkey GA, Rogers MJ, Waters AP, McCutchan TR 1994a. Plasmodium: the developmentally regulated ribosome. Exp Parasitol 78: 437-441.

Li J, Wirtz RA, McConkey, GA, Sattabongkot J, McCutchan TR 1994b. Transition of Plasmodium vivax ribosome types corresponds to sporozoite differentiation in the mosquito. Mol Biochem Parasitol 65: 283-289.

Lowry OH, Rosebrough NJ, Tarr AL, Randall RJ 1951. Protein measurement with the Folin phenol reagent. J Biol Chem 193: 265-273.

McConkey GA, Rogers MJ, McCutchan TF 1997. Inhibition of Plasmodium falciparum protein synthesis. Targeting the plastid-like organelle with thiostrepton. J Biol Chem 272: 2046-2049.

Perkins M 1988. Stage-dependent processing and localization of a Plasmodium falciparum protein of 130,000 molecular weight. Exper Parasitol 65: 6168.

Roberts BE, Paterson BM 1973. Efficient translation of tobacco mosaic virus RNA and rabbit globin 9S RNA in a cell-free system from commercial wheat germ. Proc Natl Acad Sci USA 70: 2330-2334.

Rogers MJ, Cundliffe E, McCutchan TF 1998. The antibiotic micrococcin is a potent inhibitor of growth and protein synthesis in the malaria parasite. Antimicrobial Ag Chem 42: 715-716.

Rogers MJ, Gutell RR, Damberg SH, Li J, McConkey GA, Waters AP, McCutchan TF 1996. Structural features of the large subunit rRNA expressed in Plasmodium falciparum sporozoites that distinguish it from the asexually expressed subunit rRNA. RNA 2: $134-145$.

Ruenwongsa P 1985. Preparation of malaria parasites from experimental animals. In S Panyim, P Wilairat \& Y Yuthavong (eds), Application of Genetic Engineering to Research on Tropical Disease Pathogens with Special Reference to Plasmodia, Geneva, p. 389-397.

Schmidt A, Schwarz RT, Gerold P 1998. Plasmodium falciparum: asexual erythrocytic stages synthesize two structurally distinct free and protein-bound glycosylphosphatidylinositols in a maturation-dependent manner. Exp Parasitol 88: 95-102.

Surolia N, Padmanaban G 1991. Chloroquine inhibits heme-dependent protein synthesis in Plasmodium falciparum. Proc Nati Acad Sci USA 88: 47864790.

Trager W, Jensen JB 1976. Human malaria parasites in continuous culture. Science 193: 673-675.

Wallach M 1982. Efficient extraction and translation of Plasmodium falciparum messenger RNA. Mol Biochem Parasitol 6: 335-342.

Wallach M, Kilejian A 1982. The importance of tRNA for the in vitro cell-free translation of messenger RNA isolated from the malaria parasite Plasmodium lophurae. Mol Biochem Parasitol 5: 245-261.

Woodland HR 1974. Changes in the polysome content of developing Xenopus laevis embryos. Dev Biol 40: 90-101. 